\title{
Gordaite as storage mineral for heavy metals from salt-rich solutions
}

\author{
K. TANDON ${ }^{1 *}$, S. HEUSS-AßBICHLER ${ }^{1}$
}

${ }^{1}$ Ludwig-Maximilians-Universität München, Theresienstr. 41, 80333 Munich *(kai.tandon@min.uni-muenchen.de)

Heavy metals pose a potential risk to the environment. Many studies have been carried out to limit the impact of these elements as pollutants. Recently, heavy metals from the anthroposphere have increasingly been discussed as potential resources and accordingly, more and more studies deal with the recovery of heavy metals from aqueous solutions. However, only few studies consider salt-rich environments.

Gordaite, $\mathrm{NaZn}_{4} \mathrm{SO}_{4}(\mathrm{OH})_{6} \mathrm{Cl} \bullet 6 \mathrm{H}_{2} \mathrm{O}$, is a $\mathrm{Zn}$-rich mineral observed in salt-rich natural environments, e.g. the San Francisco Mine in Sierra Gorda, Chile [1]. It is also a corrosion product in $\mathrm{Zn}$ and $\mathrm{Zn}-\mathrm{Mg}$ - $\mathrm{Al}$ slag heaps due to marine environment [2]. Experiments show that Gordaite can incorporate $\mathrm{Na}, \mathrm{K}, \mathrm{Ca}, \mathrm{Li}, \mathrm{NH}_{4}, \mathrm{Sr}, \mathrm{Ni}, \mathrm{Co}, \mathrm{Cu}, \mathrm{Cl}$ and $\mathrm{Br}$ [3-7]. $\mathrm{Zn}$ can be completely replaced by $\mathrm{Co}$ or by $50 \% \mathrm{Cu}[3,5]$.

We want to know: How much $\mathrm{Cu}$ can be incorporated into Gordaite? Is it possible to substitute $\mathrm{Zn}$ with $\mathrm{Cd}$ ? Which effect has the substitution on the morphology of Gordaite?

Synthesis experiments were performed to investigate the solid solution of $\mathrm{Zn}$-Cu-Gordaite: for $\mathrm{Zn}$-Gordaite, $\mathrm{ZnO}$ powder was mixed with a $1,5 \mathrm{M} \mathrm{NaCl}$ and $0,5 \mathrm{M} \mathrm{ZnSO}_{4}$ solution and periodically stirred for $120 \mathrm{~h}$. For the endmember $\mathrm{Cu}$-Gordaite, $\mathrm{CuO}$ and $\mathrm{CuSO}_{4}$ were used. Four experiments were performed with $\mathrm{ZnSO}_{4}: \mathrm{CuSO}_{4}$ ratios $0: 1$, 1:1, 3:1 and 1:0. Furthermore, the cation exchange capacity of Gordaite was tested. For this, Zn-Gordaite was synthesized and $0,5 \mathrm{M} \mathrm{CuSO}_{4}$ solution was added and periodically stirred for another $120 \mathrm{~h}$. $\mathrm{Cd}$ and $\mathrm{Zn}$ are chemically closely related. To test the solid solution of $\mathrm{Zn}$-Cd-Gordaite we performed the same experimental series with $\mathrm{Cd}$.

The first results show, that $\mathrm{Cu}$ and $\mathrm{Cd}$ can be incorporated into the structure. The synthesis of the endmembers $\mathrm{Cu}$ Gordaite and Cd-Gordaite needs to be verified. All residues are characterized by XRD and FTIR. In addition, SEM is used to determine a change in the morphology of the crystals depending on the incorporation of $\mathrm{Cd} \& \mathrm{Cu}$ into the structure.

[1] G. Adiwidjaja et al. (1997) Zeitschrift fur Krist. - New Cryst. Struct. 212, 704-707. [2] E. Diler et al. (2014) Corros. Sci. 87, 111-117. [3] S. Jahn \& T. Witzke (1999) Chem. d. E. 59, 223-232. [4] P. C. Burns et al. (1998) Eur. J. Mineral. 10, 923-930. [5] A. V. Kasatkin et al. (2017) Mineral. Mag. [6] S. A. Maruyama et al. (2017) Appl. Clay Sci. 146, 100105. [7] T. Stanimirova (2019) Appl. Clay Sci. 168, 396-408. 